\title{
The relationship between work environment and occupational accidents among fishermen in Indonesian coastal areas
}

\author{
Putri Ayuni Alayyannur, Shintia Yunita Arini
}

Department of Occupational Safety and Health, Faculty of Public Health, Universitas Airlangga, C Campus, Mulyorejo, Surabaya, East Java, Indonesia

\begin{abstract}
Background: Two-thirds of Indonesia's territory is water, creating much of the coastal area. Unfortunately, there is no data regarding the exact number and demographics of the population in coastal areas who work as fishermen. Residents who work as fishermen are at risk of work accidents. The increasingly uncertain number of fishermen makes it more difficult to analyse work accidents around the coastal areas. This study is an observational study and cross-sectional study. It aims to analyse the relationship between work environment and occupational accidents among fishermen in coastal areas.

Materials and methods: It was conducted using a quantitative approach. This study was located in the coastal areas in Sidoarjo, Tarakan, and Bangkalan. Sampling was conducted using snowball technique which obtained 56 respondents. Variables in this study included work climate, noise, lighting, and occupational accidents with data analysis using the Spearman's rank test.

Results: The results showed that work environment which included work climate, noise, and lighting had no relationship with occupational accidents among fishermen since $p$-value $>0.05$.

Conclusions: This study concludes that work climate, noise and lighting have no significant relationship with occupational accidents.
\end{abstract}

(Int Marit Health 2021; 72, 3: 195-198)

Key words: work environment, occupational accidents, fishermen

\section{INTRODUCTION}

Two-thirds of Indonesia's territory is water, creating much of the coastal area. There is no data regarding the exact number and demographics of the population in coastal areas who work as fishermen. It is difficult to collect data on the number of fishermen because they are sometimes ashamed with their job status as fishermen. Three of the coastal areas in Indonesia are the coasts of Madura, Sidoarjo and Tarakan.

Furthermore, Bangkalan Regency is located on the island of Madura which consists of 18 sub-districts: Arosbaya, Bangkalan, Blega, Burneh, Galis, Geger, Kamal, Klampis, Kokop, Konang, Kwanyar, Labang, Modung,
Sepulu, Socah, Tanah Merah, Tanjungbumi, and Tragah sub-districts. There are 10 of the 18 sub-districts bordering the sea and have an altitude of 2-100 $\mathrm{m}$ above sea level. Sidoarjo area borders Madura Strait in the east. In general, the coastal area of Sidoarjo has many rivers that flow out into the Java Sea. Tarakan City is one of the areas in the northern part of East Kalimantan Province. It has a total area of $657.33 \mathrm{~km}^{2}$ consisting of $38.2 \%$ of land and $61.8 \%$ or $406.53 \mathrm{~km}$ of oceans. This shows that most of this area is water or coastal areas.

In fact, occupational accidents in one industry have caused considerable losses to business owner. The disadvantage is of course even greater if the business owner has

Dr. Putri Ayuni Alayyannur, Department of Occupational Safety and Health, Faculty of Public Health, Universitas Airlangga, C Campus, Mulyorejo, Surabaya, East Java,

Indonesia, e-mail: putri.a.a@fkm.unair.ac.id

This article is available in open access under Creative Common Attribution-Non-Commercial-No Derivatives 4.0 International (CC BY-NC-ND 4.0) license, allowing to download articles and share them with others as long as they credit the authors and the publisher, but without permission to change them in any way or use them commercially. 
several industries. Thus, aspects of Occupational Safety and Health (K3) in informal industry need to be encouraged. Occupational accidents and diseases can be minimised by the presence of $\mathrm{K} 3$ among informal sector workers, including fishermen. The more it is underestimated, the more fishermen experience occupational accidents. This is exacerbated by the large number of work accidents in informal sector that have not been recorded and recognised.

This study aims to analyse the relationship between work environment and occupational accidents among fishermen in coastal areas. Work environment in this study is the fishermen's perception of work climate, noise, lighting while working.

\section{MATERIALS AND METHODS}

This study is a quantitative research with observational research type. It is a cross-sectional study, which was located in the coastal area of Sidoarjo Regency, Tarakan City, and Bangkalan Regency.

Population in this study were all fishermen in coastal areas in Sidoarjo, Tarakan City, and Bangkalan Regency. By using snowball sampling technique, 56 respondents were obtained. This study has obtained Ethical Clearance No. 84/EA/KEPK/2020 from Health Research Ethics Committee, Faculty of Public Health, UNAIR.

We conducted interviews with a questionnaire guide that had been made based on Figure 1; this was because not all fishermen who were respondents in this study could read and write. Interviews were conducted by one person who had been trained by researchers so as to minimise bias. We tested the validity and reliability before this research was conducted on 15 respondents. The results showed that all questionnaires were valid and reliable.

Variables in this study included work climate, noise, lighting, and occupational accidents. The data obtained were then analysed. Data analysis was performed using data processing software. Significance test between the two variables was carried out using the Spearman's rank test. This was conducted to determine degree of closeness of the relationship between questionnaire results for one variable and questionnaire results for other variables. There is no relationship between one variable and another if the level of significance ( $p$ value $>0.05$ ).

\section{RESULTS}

Work climate in this study was divided into two categories: disturbed and undisturbed. Table 1 shows that most respondents (92.9\%) felt disturbed by work climate in their work environment in the coastal areas of Sidoarjo, Madura, and Tarakan.

More importantly, noise in this study was divided into two categories: disturbed and undisturbed. Based on Table 1,
1. Ever had an accident at work.
a. Yes
b. No

2. Have had an accident while traveling to or from work.
a. Yes
b. No

3. When did the accident occur?

4. In the last 6 months, how many times have you had an accident at work?.

5. Mention the type of work accident!
a. date date

b.

6. Do you feel disturbed by the working climate conditions in your workplace?
a. Yes
b. Not

7. Are you bothered by noise conditions in your workplace?
a. Yes
b. Not

9. Are you bothered by the lighting conditions in your work environment?
a. Yes
b. Not

Figure 1. Questionnaire

Table 1. Frequency distribution of work climate in the coastal areas of Sidoarjo, Madura, and Tarakan in 2020

\begin{tabular}{lll}
\hline Category & Frequency & Percentage (\%) \\
\hline Work climate & & \\
Disturbed & 52 & 92.9 \\
Undisturbed & 4 & 7.1 \\
Total & 56 & 100.0 \\
Noise & & \\
Disturbed & 49 & 87.5 \\
Undisturbed & 7 & 12.5 \\
Total & 56 & 100.0 \\
Lighting & & \\
Disturbed & 54 & 96.4 \\
Undisturbed & 2 & 3.6 \\
Total & 56 & 100.0
\end{tabular}

it can be seen that the majority of respondents (87.5\%) stated that they were disturbed by noise in their work environment in the coastal areas of Sidoarjo, Madura, and Tarakan.

Additionally, lighting in this study was divided into two categories: disturbed and undisturbed. Based on Table 1, it can be concluded that most of the respondents (96.4\%) stated that they were disturbed by lighting in work environment in the coastal areas of Sidoarjo, Madura, and Tarakan. 
Table 2. Analysis of the relationship between work environment factors and occupational accidents among fishermen in the coastal areas of Sidoarjo, Madura, and Tarakan in 2020

\begin{tabular}{lll}
\hline Work climate & $\begin{array}{l}\text { Occupational } \\
\text { accidents }\end{array}$ & Conclusion \\
Correlation coefficient & -0.132 & Not significant \\
Sig. (2-tailed) & 0.334 & \\
Noise & & \\
Correlation coefficient & -0.239 & Not significant \\
Sig. (2-tailed) & 0.076 & \\
Lighting & & \\
Correlation coefficient & 0.122 & Not significant \\
Sig. (2-tailed) & 0.372 &
\end{tabular}
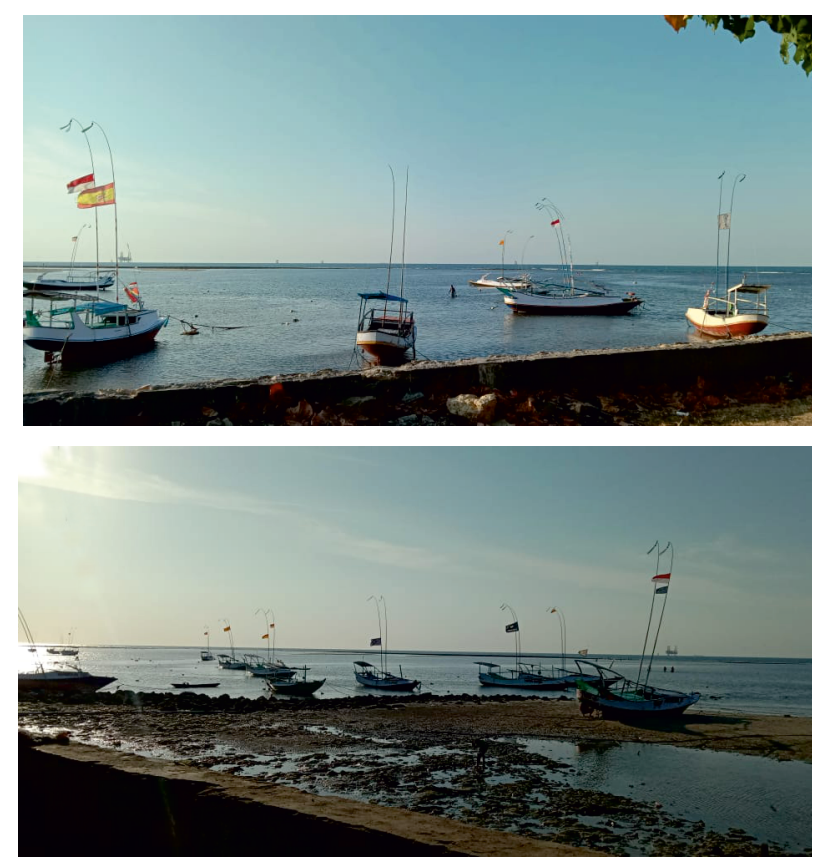

Figure 2. The boats on shore located for the daylight

Environmental factors in this study consisted of work climate, noise, and lighting. Based on the Spearman's rank test in Table 2, it was shown that those three environmental factors had no relationship with occupational accidents since the overall p-value is greater than 0.05. Based on Figure 2, the lighting for fishermen are coming from the sun (daylight) and moon (night). Thus, work environment factors in this study had no relationship with occupational accidents.

\section{DISCUSSION THE RELATIONSHIP BETWEEN WORK CLIMATE AND OCCUPATIONAL ACCIDENTS}

The majority of fishermen in the coastal areas of Sidoarjo, Madura and Tarakan claimed that they were disturbed by work climate in the workplace. However, there was only a minority of fishermen who had experienced occupational accidents both at work and on their way. Based on the analysis of the relationship, there was no relationship between work climate and occupational accidents.

Several studies have shown that work climate, especially hot weather, has a positive but inappropriate relationship with occupational accidents. This is because the possible mechanism is that hot weather can cause fatigue, decreased psychomotor abilities, loss of concentration, and decreased alertness that can lead to occupational accidents [1]. It is in line with a research conducted at a construction company which shows a relationship between work environment temperature and work stress [2]. Moreover, a research conducted on workers in ship repair in a company shows that work climate affects the occurrence of work fatigue [3]. Therefore, although most fishermen in the coastal areas of Sidoarjo, Madura, and Tarakan claimed that they were disturbed by work climate, there was actually no relationship between work climate and occupational accidents since there were mechanisms having a greater role in occupational accidents.

\section{THE RELATIONSHIP BETWEEN NOISE AND OCCUPATIONAL ACCIDENTS}

The majority of fishermen in the coastal areas of Sidoarjo, Madura and Tarakan claimed that they were disturbed by noise at work, but there was only a minority of fishermen who had experienced occupational accidents both at work and on their way. Thus, there was no relationship between noise and occupational accidents.

Results of a research conducted on workers in spinning companies show that noise has a strong relationship with work stress [4]. It is supported by a research conducted on workers in body frame in a company which shows a relationship between noise and work stress [5]. In addition, noise also has a significant relationship with worker fatigue in machine-building companies [6]. Based on these studies, it can be seen that noise has a relationship with work stress and fatigue. However, the noise stated to be disturbing by fishermen in the coastal areas of Sidoarjo, Madura, and Tarakan had no significant relationship with work accidents. This is probably due to other mechanisms caused by noise that can affect occupational accidents, so that noise does not directly affect work accidents. Therefore, it is very important to control noise in the workplace.

\section{THE RELATIONSHIP BETWEEN LIGHTING AND OCCUPATIONAL ACCIDENTS}

The majority of fishermen in the coastal areas of Sidoarjo, Madura and Tarakan claimed that they were disturbed by lighting in the workplace. However, there was only a minority 
of fishermen who had experienced occupational accidents both at work and on their way. Based on the analysis of the relationship, there was no relationship between lighting and occupational accidents.

Unsuitable lighting can interfere with visual comfort and are an indirect cause of occupational accidents [7]. Results of a research conducted on informal workers in market indicate that lighting has a significant relationship with the incidence of knife cuts [8]. However, this is contrary to results of this study on fishermen in the coastal areas of Sidoarjo, Madura, and Tarakan, which found that lighting in the workplace had no relationship with occupational accidents. It is in line with a research conducted on musical instrument craftsmen in a village which shows that there is no significant relationship between lighting and occupational accidents [9].

Lighting in the fishermen's workplace does not show a significant relationship with occupational accidents since there may be other factors that have a significant relationship. However, it is still necessary to improve the quality of lighting considering that the majority of fishermen felt disturbed with bad lighting while working. Suitable lighting can support fishermen's productivity at work [10].

\section{WEAKNESSES AND STRENGTHS OF RESEARCH}

The weakness in this study is the data collection technique used so that the number of respondents obtained is only small. It is necessary to expand the criteria in taking research respondents so that the number can be greater. The advantage of this research is the provision of research enumerators so that fishermen who cannot read and write can still be involved in this research.

\section{CONCLUSIONS}

Based on the results of the Spearman's rank test, work environment factors including work climate, noise, and lighting have no significant relationship to occupational accidents since $p$ value $>0.5$.

\section{Conflict of interest: None declared}

\section{REFERENCES}

1. Varghese B, Hansen A, Bi P, et al. Are workers at risk of occupational injuries due to heat exposure? A comprehensive literature review. Safety Science. 2018; 110: 380-392, doi: 10.1016/j.ssci.2018.04.027.

2. Lukas L, Suoth L, Wowor R. Hubungan antara Suhu Lingkungan Kerja dan Jam Kerja dengan Stres Kerja di PT Adhi Karya (Persero) Tbk Unit Manado Proyek Universitas Sam Ratulangi. Jurnal Kesmas. 2018; 7(4): 1-9.

3. Suryaningtyas Y, Widajati N. Iklim Kerja Dan Status Gizi Dengan Kelelahan Kerja Pada Pekerja Di Ballast Tank Bagian Reparasi Kapal Pt. $X$ Surabaya. Jurnal Manajemen Kesehatan Yayasan RS.Dr. Soetomo. 2017; 3(2): 225, doi: 10.29241/jmk.v3i1.83.

4. Budiawan W, Ulfa E, Andarani P. Analisis Hubungan Kebisingan Mesin dengan Stres Kerja (Studi KAsus: Mesin Two for One Twister (TFO) PT XYZ). Jurnal Presipitasi. 2016; 13(1): 1-7.

5. Amir J, Wahyuni I, Ekawati C. Hubungan Kebisingan, Kelelahan Kerja, dan Beban Kerja Mental terhadap Stres Kerja pada Pekerja Bagian Body Rangka PT X. Jurnal Kesehatan Masyarakat. 2019; 7(1): 345-350.

6. Suryaatmaja A, Pridianata VE. Hubungan antara Masa Kerja, Beban Kerja, Intensitas Kebisingan dengan Kelelahan Kerja di PT Nobelindo Sidoarjo. Journal of Health Science and Prevention. 2020; 4(1): 14-22, doi: 10.29080/jhsp.v4i1.257.

7. Sawicki D, Wolska A. Objective assessment of glare at outdoor workplaces. Building and Environment. 2019; 149: 537-545, doi: 10.1016/j. buildenv.2018.12.049.

8. Suwignyo S, Dhina D, Rahayu S. Hubungan Faktor Penyebab Kecelakaan Kerja dengan Kejadian Tersayat pada Pembersih Bawang di Pasar Segiri dan Pasar Kedondong Samarinda. KESMAS UWIGAMA: Jurnal Kesehatan Masyarakat. 2019; 4(2): 79, doi: 10.24903/ kujkm.v4i2.466.

9. Juliana, Purna I, Aryana I. Faktor-Faktor yang Berhubungan dengan Kecelakaan Kerja pada Pengrajin Gong di Dusun Tihingan, Kabupaten Klungkung Tahun 2018. Jurnal Kesehatan Lingkungan. 2018; 8(2): 82-91.

10. Hoffman G, Guvler V, Griesmacher A, et al. Effects of variable lighting intensities and colour temperatures on sulphatoxymelatonin and subjective mood in an experimental office workplace. Appl Ergon. 2008; 39(6): 719-728, doi: 10.1016/j.apergo.2007.11.005, indexed in Pubmed: 18164275. 